\title{
Root cell growth and division in soybean in the presence of base trichoderma and Bradyrhizobium japonicum bioproducts
}

\author{
Luana da Silva Cadore ';Kássia Cauana Trapp "; Rosana Taschetto Vey "II \\ Lucas Dotto 'v ; Solange Bosio Tedesco v ; Antonio Carlos Ferreira da Silva VI
}

\section{ABSTRACT}

The objective of this work was to evaluate the effect of commercial formulations of biological products on mitotic index and root growth, as well as on the initial development of soybean crop. A soybean cultivar Nidera 5909 was used, composed of four commercial bioformulates that had in its composition Trichoderma harzianum, Trichoderma sp. Bradyrhizobium japonicum. The products used were tested in combination or isolated for soybean seed inoculation in a randomized experimental design. In the variable length of shoot using Trichoderma sp., B. japonicum peat and Trichoderma sp. associated with B. japonicum peat did not differ from the control treatment but differed from the others. There was an increase in root length of soybean seedlings for the treatments $T$. harzianum $+B$. japonicum liquid and $T$. harzianum + B. japonicum peat compared to the control, as well as an increase in the mitotic index for the same treatments. The treatments $T$. harzianum $+B$. japonicum liquid and T. harzianum + B. japonicum provided higher root growth of soybean seedlings and higher initial plant growth.

Keywords: Bioproducts; Microorganisms; Germination; Mitotic index; Glycine max

\footnotetext{
I Universidade Federal de Santa Maria, Santa Maria, Brazil. luanascadore@yahoo.com.br

" Universidade Federal do Rio Grande do Sul, Porto Alegre, Brazil. kassiacauanatrapp@yahoo.com.br

III Universidade Federal de Santa Maria, Santa Maria, Brazil. rosanatv2103@yahoo.com.br

IV Universidade Tecnológica Federal do Paraná, Pato Branco, Brazil. lucas-dotto@hotmail.com

v Universidade Federal de Santa Maria, Santa Maria, Brazil. solatedesco@gmail.com

vı Universidade Federal de Santa Maria, Santa Maria, Brazil. acfsilva2@uol.com.br
} 


\section{INTRODUCTION}

Soybean (Glycine $\max$ (L.) Merril) is grown worldwide, with the United States, Brazil and Argentina being its main producers contributing approximately $82 \%$ of world production. Brazil is the second largest producer of grain, being in the 2017/2018 harvest responsible for exporting 34,451 thousand tons until July 2018 (CONAB, 2018).

Aiming at the good development of plants it is necessary to adopt techniques that improve the crop performance, among them, the seed treatment. It aims to provide defensive conditions during seedling germination and emergence, allowing the crop to express its maximum potential for initial development (CASTRO et al., 2008). For soybeans, seed treatment is performed using products of chemical and biological origin. The use of Bradyrhizobium japonicum-based biological products in soybeans is linked to biological nitrogen fixation and increased crop yield through soil enrichment (OYEKANMI et al., 2007). The bioproducts based on Trichoderma spp. Based act as seed protectors in the soil, being potential biocontrol agents and as growth promoters for many plants (JOHN et al., 2010). The use of bioproducts combined or not may be an alternative, although little is known about their role in the development of soybean plants when using products based on fixing bacteria in combination with other microorganisms.

Baker (1989) already reported the frequent use of fungi and bacteria in several researches, aiming to promote crop productivity, as well as for biological control of diseases and or insects. The author also reports that the fungi can be antagonists to phytopathogens, besides being able to produce antibiotics, competing for nutrients, as well as parasitizing plants and other fungi.

Among the known fungi for seed treatment, the genus Trichoderma corresponds to the fungi found preferentially in soils of temperate and tropical regions. These are mainly used for the control of phytopathogens by acting as hyperparasites, and also in the antibiosis, competition, and induction of plant resistance against phytopathogens (MACHADO, 2012). They are also used to promote 
plant growth and development, even in the absence of phytopathogens, a fact related to the ability of this genus to produce plant growth stimulating phytohormones and provide greater efficiency in nutrient availability and absorption by the plant. In addition, they have the ability to colonize the most varied organs of the plant and the rhizosphere (França et al., 2017; LUCON, 2009). However, trichoderma isolates may differ in action on plant growth and may in some cases be neutral and even negative (CHAGAS et al., 2017).

There are few studies on the action of trichoderma-based bioproducts in combination with biological products that have soybean growth-promoting bacteria as their active ingredient (ANDRADE et al., 2016). Entre essas bactérias está o gênero Bradyrhizobium sp. habitantes naturais do solo e responsáveis pela fixação biológica do nitrogênio $\left(\mathrm{N}_{2}\right)$. Essas bactérias penetram nas raízes das plantas, proporcionando a formação de células específicas, os nódulos, que são os principais responsáveis pela fixação biológica do $\mathrm{N}_{2}$ (HUNGRIA et al., 2001) e podem influenciar o desenvolvimento inicial das plantas.

The evaluation of the mitotic index in plant roots helps in the identification of adequate or inadequate cell multiplication of plant cells and is also one of the forms of cytogenetic evaluation (TEDESCO \& LAUGHINGHOUSE, 2012), serving to observe the root growth effects caused by these bioproducts, combined or not, stimulate mitotic division in root system cells.

Thus, the aim of this work was to evaluate the effect of Bradyrhizobium and trichoderma formulated commercial biological product in an isolated and associated way, on the root tips mitotic index as well as on the germination process and initial growth in plants of and emergence of. soybean plants.

\section{MATERIAL AND METHODS}


The experiment was carried out at the Plant Cytogenetics and Genotoxicity and Plant - Microorganisms Interaction Laboratories, both located at the Center for Natural and Exact Sciences (CCNE) of the Federal University of Santa Maria (UFSM) -RS.

The variety soybean seeds NA 5909, free from chemical treatment, were supplied by Cooperativa Agropecuária de São Pedro do Sul Ltda - COOPERAGRO, RS. The reason for choosing the cultivar is because it is among the most cultivated in central Rio Grande do Sul. Four commercial products were used, one based on T. harzianum (Ecotrich ${ }^{\circledR}$ - 1.1010 UFC.g-1, Balagro Tecnologia LTDA, in the form of wettable powder - WP) and the other based on Trichoderma sp. (Trichodel ${ }^{\circledR}$ - 1,109 UFC.mL-1, ECCB biological inputs, in liquid form), and two B. japonicum-based products, these being in liquid and peat form (Bionutriß Liquid Soybean Inoculant 5,109 viable cells.mL -1 of commercial product, Bioagro - Agricultural Industry and Trade LTDA, and Bionutri® Peat Inoculant for soybean - 3,109 viable cells.g-1 of commercial product, Bioagro - Agricultural Industry and Trade LTDA), both provided by the manufacturing companies.

The experimental design was completely randomized composed of nine treatments and three replications, the treatments represented in Table 1:

Table 1 - Description of the doses of each bioformulate used in the treatment of soybean seeds ( $50 \mathrm{~g}$ of seed for each treatment)

\section{Treatments}

Control - no application

0,012 g Trichoderma harzianum

0,08 mL Trichoderma sp.

0,04 mL Bradyrhizobium japonicum liquid

0,04 g Bradyrhizobium japonicum peat

0,012 g Trichoderma harzianum $+0,04 \mathrm{~mL}$ Bradyrhizpbium japonicum liquid

0,012 g Trichoderma harzianum + 0,04 g Bradyrhizobium japonicum peat

0,08 mL Trichoderma sp. + 0,04 mL Bradyrhizobium japonicum liquid

0,08 mL Trichoderma sp. + 0,04 g Bradyrhizobium japonicum peat

The doses recommended by the manufacturers are: T. harzianum (Ecotrich ${ }^{\circledR}$ ) at a dose of $30 \mathrm{~g}$, Trichoderma sp. (Trichodel $($ ) at a dose of $200 \mathrm{~mL}$ and B. japonicum 


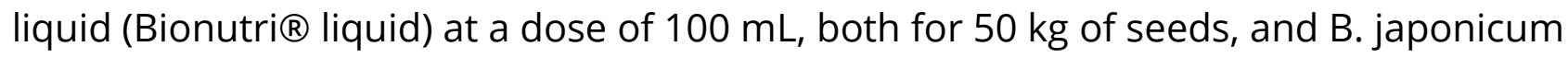
peat (Bionutri ${ }^{\circledR}$ turfa) at a dose of $300 \mathrm{~g}$ to $150 \mathrm{~kg}$ of seeds. The doses presented in Table 1 were adjusted for the amount of soybean seeds used in this experiment.

Initially, the germination test was performed using four replications of 50 seeds, which were treated according to the treatments described above. Subsequently, they were sown on germitest paper previously moistened with distilled water equivalent to 2.5 times the weight of dry paper. The method for germination was through paper rolls, which were allocated in plastic bags and sent to germination chamber with temperature of $25^{\circ} \mathrm{C}$ and photoperiod of 12 hours (BRASIL, 2009). Germination counts were performed at five and eight days after sowing, and the values were considered as a percentage (BRASIL, 2009).

Eight days after sowing, 10 random seedlings were selected, from which we evaluated the shoot and root length (BRASIL, 2009). Subsequently, the seedlings were collected and weighed on a BEL Engineering MARK M1203i class II precision scale, and their fresh matter weight was determined. Afterwards, they were placed in a drying oven at $55^{\circ} \mathrm{C}$, remaining until the weight stabilization, and then the dry matter was determined.

Six random roots were selected, which were separated and placed in flasks containing Carnoy 3: 1 fixative (ethanol: acetic acid) for 24 hours to stop cell division. Subsequently, the roots were stored in $70 \%$ ethanol after refrigeration, until the preparation of the slides for analysis.

Eight slides were prepared per treatment and 250 cells per slide were analyzed, totaling 1000 cells per treatment. The slides were prepared by the adapted crushing technique by Guerra \& Souza (2002), which consisted primarily of root hydrolysis in $1 \mathrm{~N}$ hydrochloric acid $(\mathrm{HCL})$ for 5 minutes and then washed in distilled water. Then the meristematic region was sectioned, placed on the slide and stained with $2 \%$ acetic orcein. The slides were observed under a 100X magnification optical microscope with the aid of immersion oil.

The analysis of the cells took into consideration the phase of the cell cycle in which they were, and could be interphase, prophase, metaphase, anaphase and 
telophase. Mitotic index (MI) was calculated based on the percentage of dividing cells in relation to the total number of cells analyzed.

The data obtained were compared by Scott-Knott test at 5\% probability of error, using the Sisvar software (FERREIRA, 2014).

\section{RESULTS AND DISCUSSIONS}

The interaction between microorganisms and the plant can have a positive, negative and even neutral effect. Badawi et al. (2011) reported that the use of Bradyrhizobium sp. associated with Trichoderma harzianum showed synergistic interaction, stimulating the growth of plants of Arachis hypogea L., causing increase in dry weight of shoots and roots when compared to the control. Ventura and Bernilla (2014) observed that for variables such as stem length and average leaf length of Capsicum annuum, there was no statistically significant difference when $T$. viride associated with B. yuanmingense was used in relation to the control treatment. Both authors demonstrate the various effects of the association of microorganisms on different cultures.

The results obtained for soybean seed germination variable (G\%) are presented in Table 2. It was observed that there was no significant difference between the studied treatments, except for those in which $T$. harzianum associated B. japonicum liquid and Trichoderma sp. associated B. japonicum peat, which showed a reduction in seed germination percentage when compared to the control treatment, which reduction was $2.05 \%$ and $2.56 \%$, respectively.

Treatments using Trichoderma sp., B. japonicum peat and Trichoderma sp. associated with B. japonicum peat did not differ statistically from the control in relation to the variable length of shoot (CPA). However, they differed statistically from the other treatments, which remained with lower shoot growth when compared to the control and using Trichoderma sp., B. japonicum turfa and Trichoderma sp. associated $B$. japonicum peat (TABLE 2). Data regarding the root length (CR) variable inferred that the treatments using $T$. harzianum associated $B$. japonicum liquid and $T$. 
harzianum associated $B$. japonicum peat showed the best results for root development, with an increase of $36 \%, 25 \%$ and $21.29 \%$ respectively, when compared to the control treatment (TABLE 2).

Table 2 - Germination (G\%), shoot length (CPA) and root length (CR) of soybean cultivar ND 5909, at eight days after sowing

\begin{tabular}{lccc}
\hline Treatment & G \% & CPA (cm) & CR (cm) \\
\hline Control & $97,5 \mathrm{a}$ & $5,31 \mathrm{a}$ & $6,95 \mathrm{~d}$ \\
T. harzianum & $98,5 \mathrm{a}$ & $4,29 \mathrm{~b}$ & $5,29 \mathrm{f}$ \\
Trichoderma sp. & $99,5 \mathrm{a}$ & $4,78 \mathrm{a}$ & $7,77 \mathrm{c}$ \\
B. japonicum liquid & $98,0 \mathrm{a}$ & $3,99 \mathrm{~b}$ & $5,54 \mathrm{f}$ \\
B. japonicum peat & $97,5 \mathrm{a}$ & $4,94 \mathrm{a}$ & $6,01 \mathrm{e}$ \\
T. harzianum + B. japonicum liquid & $95,5 \mathrm{~b}$ & $3,97 \mathrm{~b}$ & $9,47 \mathrm{a}$ \\
T. harzianum + B. japonicum peat & $98,5 \mathrm{a}$ & $3,36 \mathrm{~b}$ & $8,43 \mathrm{~b}$ \\
Trichoderma sp. + B. japonicum liquid & $98,5 \mathrm{a}$ & $3,81 \mathrm{~b}$ & $5,40 \mathrm{f}$ \\
Trichoderma sp. + B. japonicum peat & $95,0 \mathrm{~b}$ & $4,67 \mathrm{a}$ & $6,14 \mathrm{e}$ \\
\hline CV (\%) & 2,02 & 12,97 & 6,00 \\
\hline
\end{tabular}

*Averages followed by the same letter do not differ statistically from each other by the Scott-Knott test at the $5 \%$ probability level.

The use of Trichoderma and chemicals in the treatment of guava seeds caused a reduction in seed germination percentage when compared to treatment without bioproducts (FANTINEL et al., 2015). This data differs from the results obtained in this experiment, since only when used Trichoderma harzianum associated B. japonicum liquid and Trichoderma sp. associated with B. japonicum peat reduced seed germination percentage.

Using rhizobium and Trichoderma harzianum strains in black oats, Machado et al. (2011), observed that both in isolated and associated form, there was stimulation by the tested organisms on the plants, promoting their growth, as well as the increase of plant mass of the aerial part of the plants. In Capsicum annum, Ventura and Bernilla (2014) observed that 20 and 30 days after inoculation with Trichoderma viride and Bradyrhizobium yuanmingense there was an increase in the average root length of the seedlings compared to the control treatment (without inoculation). 
In evaluating the germination percentage of soybean seeds, Ayoubi et al. (2012) observed that there was no significant difference between treatments using Trichoderma spp. and Bradyrhizobium japonicum in isolation and associated, when compared with the control treatment. For the variables root length, shoot length, root fresh and dry matter, and finally shoot fresh matter, there was a significant increase for the same treatments studied, being this increase from 2 to 2.5 times the values obtained with the control treatment for the variables analyzed (AYOUBI et al., 2012).

Regarding the data presented in Table 3, it was observed that the fresh seedling mass in the treatments $B$. japonicum peat and Trichoderma sp. associated B. japonicum peat did not differ from control treatment. For seedling dry matter, there was no difference between the treatments studied. This result corroborates that found by Ventura and Bernilla (2014), where they observed that for the shoot dry matter variable of Capsicum annuum seedlings, at 20 and 30 days after inoculation with $T$. viride and B. yuanmingense also did not occur statistically significant difference when compared to control (no inoculation with biological products).

Table 3 - Fresh matter (MF) and dry matter (DM) of ND 5909 soybean seedlings at eight days after sowing

\begin{tabular}{lcc}
\hline Treatments & MF Seedling (g) & MS Seedling (g) \\
\hline Control & $7,43 \mathrm{a}$ & $1,48 \mathrm{a}$ \\
T. harzianum & $6,54 \mathrm{c}$ & $1,62 \mathrm{a}$ \\
Trichoderma sp. & $6,88 \mathrm{~b}$ & $1,58 \mathrm{a}$ \\
B. japonicum liquid & $6,03 \mathrm{c}$ & $1,64 \mathrm{a}$ \\
B. japonicum peat & $7,36 \mathrm{a}$ & $1,62 \mathrm{a}$ \\
T. harzianum + B. japonicum liquid & $6,46 \mathrm{c}$ & $1,62 \mathrm{a}$ \\
T. harzianum + B. japonicum peat & $6,23 \mathrm{c}$ & $1,65 \mathrm{a}$ \\
Trichoderma sp. + B. japonicum liquid & $6,38 \mathrm{c}$ & $1,56 \mathrm{a}$ \\
Trichoderma sp. + B. japonicum peat & $7,36 \mathrm{a}$ & $1,59 \mathrm{a}$ \\
\hline CV (\%) & 3,69 & 4,0 \\
\hline
\end{tabular}

*Averages followed by the same letter do not differ statistically from each other by the Scott-Knott test at the $5 \%$ probability level. 
Chagas Junior et al. (2012) evaluated the shoot and root dry matter of cowpea 40 days after planting, the authors observed that between the rhizobium (Bradyrhizobium) and Trichoderma sp. there was a significant difference for the analyzed variables. In the same study it was observed that for biomass production (shoot dry matter, root dry matter and total dry matter), the treatment using rhizobium and trichoderma inoculation in the seed 15 days after planting and rhizobium inoculation and trichoderma in the soil at 15 days after planting showed better results than those obtained with the control treatment, where only nitrogen fertilization was used (CHAGAS JUNIOR et al., 2012).

According to Granados et al. (2016), the shoot dry matter of triticale plants was higher when associated treatment of Bradyrhizobium sp. and Trichoderma harzianum, compared to the other treatments studied, indicating that the microorganisms acted synergistically, benefiting this variable that is considered a productive indicator of the culture. For root dry matter, the authors observed that the use of Bradyrhizobium (strain Jj6) associated with Trichoderma harzianum had better results than the control treatment, proving that the association of these microorganisms provided positive effects on root development of triticale (GRANADOS et al. al., 2016).

Table 4 shows the data regarding the number of interphase cells, the number of dividing cells (prophase, metaphase, anaphase and telophase) and finally the mitotic index of cells of the root meristematic region of soybean. Regarding the mitotic index it was observed that only the treatments using T. harzianum associated B. japonicum liquid and T. harzianum associated B. japonicum peat differed from the control treatment, presenting an increase of $9.31 \%$ and $1.24 \%$ of cells in division respectively.

The treatments using $B$. japonicum liquid and Trichoderma sp. associated $B$. japonicum liquid presented a reduction in the mitotic index when compared to the control treatment $45.96 \%$ and $37.26 \%$, respectively (TABLE 4). Na análise da proliferação celular, foram encontradas todas as fases do ciclo celular (interfase, prófase, metáfase, anáfase e telófase) (Figura 1). 
Tabela 4 - Número de células meristemáticas de soja analisadas em interfase, em divisão e os índices mitóticos (IM)

\begin{tabular}{lccc}
\hline Treatments & Interphase cells & Cells in mitotic division & IM \\
\hline Control & 1839 & 161 & $8,05 \mathrm{~b}$ \\
T. harzianum & 1853 & 147 & $7,35 \mathrm{~b}$ \\
Trichoderma sp. & 1855 & 145 & $7,25 \mathrm{~b}$ \\
B. japonicum liquid & 1913 & 87 & $4,35 \mathrm{C}$ \\
B. japonicum peat & 1848 & 152 & $7,60 \mathrm{~b}$ \\
T. harzianum + B. japonicum liquid & 1804 & 196 & $8,80 \mathrm{a}$ \\
T. harzianum + B. japonicum peat & 1814 & 186 & $8,15 \mathrm{a}$ \\
Trichoderma sp. + B. japonicum liquid & 1899 & 101 & $5,05 \mathrm{c}$ \\
Trichoderma sp. + B. japonicum peat & 1849 & 151 & $7,55 \mathrm{~b}$ \\
\hline CV (\%) & - & - & 13,17 \\
\hline
\end{tabular}

*Averages followed by the same letter do not differ statistically from each other by the Scott-Knott test at the $5 \%$ probability level.

Figure 1 - Prophase (1), metaphase (2), anaphasis (3) and telophase (4) cells used to calculate the Glycine max mitotic index. $10 \mu \mathrm{m}$ scale

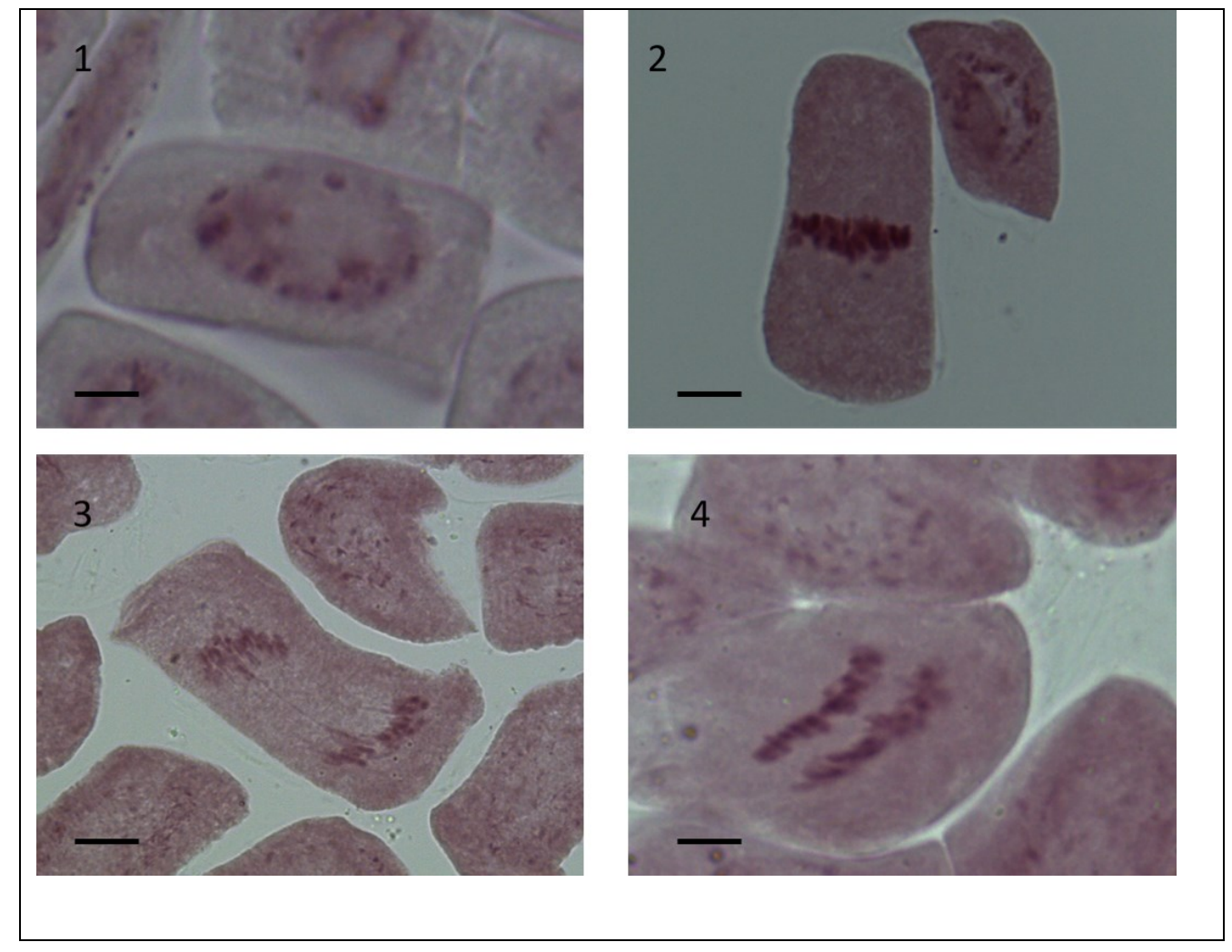


As shown in Table 2, treatments using $T$. harzianum associated with $B$. japonicum liquid and T. harzianum associated with B. japonicum peat showed the best results with respect to root development. It is possible to verify that the same treatments obtained the highest mitotic index. These data infer that the use of $T$. harzianum associated with B. japonicum in liquid and peat formulations provides better root development, which is corroborated by the results of the mitotic index analysis of soybean root meristematic cells.

By using metabolites from different strains of trichoderma Aguiar et al. (2015) observed that 2B2, 2B12 and $\mathrm{C} 1$ provided an increase in the mitotic root index of Allium cepa L., statistically differing from the control treatment, inferring in the ability of these isolates to interfere in the cell division process. When using the Trichodermil $®$ and Agrotrich $\circledast$ bioproducts, isolated from Trichoderma harzianum 2B22, and Trichoderma viride TSM1 and TSM2, compared to the control treatment, they did not differ statistically and did not interfere with root cell division (AGUIAR et al., 2015).

The increase in root, shoot, fresh and dry matter growth of root and shoot fresh matter in soybean plants treated with Trichoderma spp. and B. japonicum, in association, may be related to the synergistic relationship between the studied microorganisms (AYOUBI et al., 2012), and it can be inferred that the combined use of these microorganisms provided better development in soybean plants.

Mitotic index analysis indicated some isolates of Trichoderma spp. with the potential to induce increased cell division of Allium cepa root tips (AGUIAR et al., 2015). Thus, it is possible to infer that the mitotic index is potentially related to the higher root development, as well as the identification of bioproducts that act positively on the root development of soybean seedlings.

\section{CONCLUSIONS}

It was concluded that the use of $T$. harzianum associated with liquid $B$. japonicum, as well as $T$. harzianum associated with B. japonicum peat provided higher 
growth of soybean seedlings, which was confirmed by the mitotic index analysis, which indicates increased cell multiplication resulting in root growth.

\section{REFERENCES}

AGUIAR, A.R.; AGUIAR, D.; TEDESCO, S.B.; SILVA, A.C.F. Efeito de metabolitos produzidos por Trichoderma spp. sobre o índice mitótico em células das pontas de raízes de Allium cepa. Bioscience Journal.2015;31(3): 934-940.

ANDRADE, A.; CONDÉ, A.; COSTA, R.; POMELA, A.; SOARES, A.; MARTINS, F.; LIMA, W.; OLIVEIRA, C. Produtividade de milho em função da redução do nitrogênio e da utilização de Azospirillum brasilense. Revista Brasileira de Milho e Sorgo.2016;15(2): 229-239.

AYOUBI, N.; ZAFARI, D.; MIRABOLFATHY, M. Combination of Trichoderma species and Bradyrhizobium japonicum in control of Phytophthora sojae and soybean growth. Journal of Crop Protection. 2012;1(1): 67-79.

BADAWI, F.Sh.F.; BIOMY, A.M.M.; DESOKY, A.H. Peanut plant growth and yeldi as influenced by co-inoculation with Bradyrhizobium and some rhizo-microorganisms under sandy loam soil conditions. Annals of Agricultural Sciences. 2011;56(1):17-25.

BAKER, R. Improved Trichoderma spp. for promoting crop productivity. TIBTECH Trends of biotechnology. 1989; 7:34-38.

BRASIL. Ministério da Agricultura, Pecuária e Abastecimento. Regras para análise de sementes/Ministério da Agricultura, Pecuária e Abastecimento. Secretaria de Defesa Agropecuária - Brasília: Mapa/ACS; 2009.

CASTRO, G.S.A.; BOGIANI, J.C.; SILVA, M.G.; GAZOLA, E.; ROSOLEM, C.A. Tratamento de sementes de soja com inseticidas e um bioestimulante. Revista Pesquisa Agropecuária Brasileira. 2008;43(10):1311-1318.

CHAGAS JUNIOR, A.F.; SANTOS, G.R.; REIS, H.B.; MILLER, L.O.; CHAGAS, L.F.B. Resposta de feijão-caupi a inoculação com rizóbio e Trichoderma sp. No errado, Gurupi, TO. Revista Verde de Agroecologia e Desenvolvimento Sustentável. 2012;7(2):242-249.

CHAGAS, L. F. B.; CHAGAS JUNIOR, A. F.; SOARES, L. P.; FIDELIS, R. R. Trichoderma na promoção do crescimento vegetal. Agricultura Neotropical. 2017;4(3):97-102.

Companhia Nacional de Abastecimento - CONAB. (2018). Acompanhamento da Safra Brasileira: grãos. (Décimo levantamento, p.118 - 130). Brasília, DF: CONAB. 
FANTINEL, V.S.; OLIVEIRA, L.M.; CASA, R.T.; ROCHA, E.C.; SNHEIDER, P.F.; VICENTE, D. Tratamentos de sementes de goiaba-serrana (Acca sellowiana): efeito na incidência de fungos e na germinação. Revista Brasileira de Biociências. 2015;13(2):84-89.

FERREIRA, D.F. Sisvar: um guia para seus procedimentos de Bootstrap em múltiplas comparações. Ciência e Agrotecnologia (UFLA). 2014;28(2):109-112.

FRANÇA, D.V.; KUPPER, K.C.; MAGRI, M.M.R.; GOMES, T.M.; ROSSI, F. Trichoderma spp. isolates with potential of phospate solubilization and growth promotion in cherry tomato. Pesquisa Agropecuária Tropical. 2017;47(4):360-369.

GUERRA, A. \& SOUZA, M.J. Como observar os cromossomos: um guia de técnicas em citogenética vegetal, animal e humana. Ribeirão Preto: FUNPEC; 2002.

GRANADOS, C.J.B.; PÉREZ, A.D.P.; CORDOVI, R.A.; SANZ, M.Q.; RODRÍGUEZ, Y.G.; NÁPOLES, F.M.; VALDÉS, A.M. Efecto de la inoculación com Bradyrhizobium sp. y Trichoderma harzianum em triticale (X. Triticosecale Wittmack), em condiciones de estrés por sequía. Pastos y Forragies. 2016;39(1):19-26.

HUNGRIA, M.; CAMPO, R.J.; MENDES, I.C. Fixação biológica de nitrogênio na cultura da soja. Circular técnica - Embrapa Cerrados. 2001;13.

LUCON, C.M.M. Promoção de crescimento de plantas com o uso de Trichoderma spp. Infobibos, Informações Tecnológicas, 2009. Acesso em 12-08-2019. Disponível em http://www.infobibos.com/artigos/2009_1/trichoderma/index.htm

MACHADO, D.F.M.; PARZIANELLO, F.R.; SILVA, A.C.F.; ANTONIOLLI, Z.I. Trichoderma no Brasil: o fungo e o bioagente. Revista de Ciências Agrárias. 2012;35(1).

MACHADO, R.G.; SÁ, E.L.S.; DAMASCENO, R.G.; HAHN, L.; ALMEIDA, D.; MORAES, T.; CAMARGO, F.A.O.; REARTES, D.S. Promoção de crescimento de Lotus corniculatus L. e Avena strigosa Schreb pela inoculação conjunta de Trichoderma harzianum e rizóbio. Revista Ciência e Natura. 2011;33(2).

TEDESCO, S.B.; LAUGHINGHOUSE, H.D. Bioindicatos of genotoxicity: The Allium cepa test. Environmental Contamination, 2012. Doi: 10.5772/1124

VENTURA, R.S.; BERNILLA, B.S. Efecto de Trichoderma viride y Bradyrhizobium yuanmingense em el crecimiente de Capsicum Annuum em condiciones de laboratório. Rebiolest. Revista Científica de Estudientes. 2014,2(2):32. 